\title{
COLLECTION OF MANUSCRIPTS FROM MALACCA KEPT IN LONDON WITH SPECIAL EMPHASIS ON ADAT RAJA-RAJA MELAYU
}

\section{(Koleksi Manuskrip Melaka di London dengan Tumpuan Khusus terhadap Adat Raja-raja Melayu)}

\author{
Jelani Harun \\ jelani@usm.my
}

School of Humanities, Universiti Sains Malaysia

Published on: 1 June 2018

To cite: Jelani Harun. (2018). Collection of manuscripts from Malacca kept in London with special emphasis on Adat Raja-Raja Melayu. Malay Literature 31(1), 29-46.

\begin{abstract}
The real situation of the manuscripts originating from the state of Malacca is still a big question. There is no arrangement in a proper listing and is still vaguely understood by society at large. The manuscripts of major works revolving around the history of the Malacca Sultanate are mostly found in other countries, in particular London and Leiden. The splendour of the Malay Sultanate in Malacca during the 15 th century seems to have left little impact on the history of Malay manuscript writing. This state of affairs leaves a gap in the history of Malay literature in Malacca as this should have been the earliest location of the Malay manuscript writing tradition. This article will discuss again this issue by conducting an initial study of the collection of manuscripts from Malacca kept in London with special emphasis on the manuscript Adat Raja-raja Melayu.
\end{abstract}

Keywords: Adat Raja-raja Melayu, Malay manuscript, Malacca Sultanate, London, Leiden

\section{Abstrak}

Kedudukan sebenar manuskrip yang berasal usul dari negeri Melaka masih lagi menjadi tanda tanya. Manuskrip tersebut masih 
belum tersusun dalam sebuah senarai yang sepatutnya, dan masih kabur dalam pengetahuan masyarakat. Manuskrip bagi karyakarya besar yang berhubungan dengan sejarah Kesultanan Melaka kebanyakannya ditemui di negeri-negeri yang lain, terutamanya di London dan Leiden. Kegemilangan Kesultanan Melayu Melaka pada abad ke-15 yang lalu seolah-olah tidak meninggalkan impak yang besar kepada sejarah penulisan manuskrip Melayu. Keadaan ini menimbulkan kelompangan dalam sejarah persuratan Melaka yang sepatutnya menjadi lokasi terawal pembentukan tradisi penulisan manuskrip Melayu. Makalah akan membicarakan semula persoalan ini dengan membuat penelitian awal terhadap koleksi manuskrip Melaka yang kini tersimpan di London dengan memberikan tumpuan khusus terhadap manuskrip Adat Raja-raja Melayu.

Kata kunci: Adat Raja-raja Melayu, manuskrip Melayu, Kesultanan Melaka, London, Leiden

\section{INTRODUCTION}

Until today, scholars are unanimous in their opinion about the status of Sulalatus Salatin and Hikayat Hang Tuah as the two great Malay works that emerged from Malay literature in Johore. Sulalatus Salatin was written or recomposed by Tun Sri Lanang at Batu Sawar, Johor Lama in 1612, while the exact location and date of the writing of Hikayat Hang Tuah have still not been determined with certainty. ${ }^{1}$ Although several versions of Sulalatus Salatin are available, the reality is, Sulalatus Salatin which describes the history of the Malay Sultanate in Malacca is the product of Johore literature. So too is Hikayat Hang Tuah which is believed to have been written in Johore in the 18th century, although it now has various versions which differ from each other. ${ }^{2}$ Unfortunately, until today both versions have not been subjected to a thorough study or philological editing by comparing all the copies of manuscripts that are available, especially the manuscripts originating from Malacca.

\section{Manuscripts from Malacca}

The total number of manuscripts originating from Malacca has not been precisely determined as the listing is not exhaustive. A small number of manuscripts originating from Malacca were only discovered as having been recorded in several catalogues but without explanation about the history of the discovery. Part of the catalogue also lists the manuscripts that are 
now kept in several libraries abroad, a list which has special characteristics including the date of writing (Ricklefs and Voorhoeve, 1977). The exact total number of manuscripts originating from Malacca may be larger than what is currently known. The rise of Malacca as the centre of the the reign of the Malay Sultanate, of trade and knowledge in the 15th century facilitated the writing of many manuscripts by writers at the Court of Malacca.

Sulalatus Salatin records the existence of several ulama in Malacca who taught religious knowledge and texts. This historiographical work also mentions Bendahara Tun Perak as an intellectual and a scholar who was skilled in writing court documents. Bendahara Tun Perak is believed to have also been involved in the writing of Undang-undang Melaka and Undangundang Laut. Unfortunately, almost the whole of the original manuscript from the court of the Malay Sultanate cannot be detected anywhere, lost in the march of time. There is a great possibility a big portion of it was destroyed when the ship, The Flor de la Mar sunk in the Straits of Malacca on its way to Portugal in the year 1511.

The glory of the Malay rulers' reign in Malacca in the 15th and early part of 16th centuries is meticulously recorded in Sulalatus Salatin and Hikayat Hang Tuah. However, the writing of both these great works of Malay literature did not take place during this period, rather it was the work of the Johore court writers in the 18th century. In fact, the publication of both these works were not based on manuscripts which originated in Malacca, but sourced from manuscripts found in other states. The sources of manuscripts for the publication of several versions of Sulalatus Salatin are as follows:

1. Sejarah Melayu (W.G. Shellabear, Malaya Publishing House, Singapura, 1896) based on three manuscripts from Singapore.

2. Sulalatus Salatin (A. Samad Ahmad, DBP, 1979) based on three manuscripts from Singapore.

3. Sulalat al-Salatin (Muhammad Haji Salleh, 1997) based on Raffles Malay 18 manuscript at Royal Asiatic Society, London dated 1812. The same manuscript was republished by Cheah Boon Kheng (1998) with the title Sejarah Melayu The Malay Annals.

4. Sulalat u's-Salatin (Ahmat Adam, Yayasan Karyawan, 2016) based on the manuscript owned by Krusenstern, Saint-Petersburg, Russia, dated 1798 . 
All the Sulalatus Salatin publications stated above are not based on manuscripts originating from Malacca, but are the product of writers and Malay manuscript copyists from other states. The same applies to the publication of Hikayat Hang Tuah which was produced by Kassim Ahmad as recently as 1964 , its source being the Javanese manuscript owned by Tengku Ibrahim ibni Tengku Muhammad (Tengku Seri Utama Raja), a member of the Kelantan royal family. The same manuscript was used for the publication of Hikayat Hang Tuah as a great Malay epic by Yayasan Karyawan in 1997.

Initial reviews found that almost all the manuscripts used by Liaw Yock Fang in publishing Undang-undang Melaka in 1976 were based on manuscripts kept in Leiden. The republication of Undang-undang Melaka or Hukum Kanun Melaka by Abu Hassan Sham (1995) was also based on important manuscripts kept in Leiden. The republication of Undang-undang Laut by Mariyam Salim (2005) was based on a manuscript copied by Ismail Datuk Kerian in Riau.

The publication of Undang-undang Melaka and Undang-undang Laut as great Malay Works by Yayasan Karyawan in 2003 were based on manuscripts kept in the Vatican City Library in Rome. Where the manuscripts were written and who were the authors of the manuscripts were not stated clearly.

The question is, where are the manuscripts written by authors or copyists from Malacca in describing the history of Malay literature in Malacca? Was Malaccan literature lacking in writers and manuscript copyists of calibre because of Malacca's fall to the Portuguese and the Dutch? Without diminishing the importance of the publication of Sulalatus Salatin, Hikayat Hang Tuah, Undang-undang Melaka and Undang-undang Laut, it is only proper that the works are republished based on manuscripts by writers and manuscript copyists from the state of Malacca to ensure authenticity of identity, preservation of Malay historical literature and the sociocultural society in Malacca.

The suggestion above needs to be taken up by researchers of Malay manuscripts, especially from among philologists, to explore and conduct a comprehensive study of manuscripts originating from Malacca. This should involve all manuscripts in and outside the country, not forgetting those in personal safekeeping. A thorough philological study should be conducted on the manuscripts from the aspect of codicology or textology, and vital descriptions about the author, date and place of writing should be given. The collection of manuscripts should include all the available ones, the major 
works as well as the minor ones, so that the path of the history of Malay literature in Malacca can be traced and described more comprehensively. Special acknowledgement should be given to important writers so that Malaccan writers' supremacy becomes more prominent.

In order to do this, a researcher of Malay manuscripts should be armed with several basic skills in philology, and at the same time understand the history of Malay literature in Malacca in the sociocultural, religious and other contexts. A philological study does not only centre on manuscript but also involves field study that requires the researcher of the manuscript to study the sociocultural history of the society, historical location, the author's biodata and so on. Why was Abdullah Munsyi who hailed from Malacca more prolific while he was in Singapore? Was it because he lacked ideas for writing in Malacca or were there other factors that drove him to pen more works in Singapore? Understanding the background of a writer is very important to philologists in interpreting the manuscripts he's studying, in particular those that contain social, religious, way of thinking, etc issues.

The following are brief descriptions of the manuscripts originating from Malacca found in London's safekeeping based on a research done in 2016. ${ }^{3}$ Emphasis is only given to the manuscripts found in the Royal Asiatic Society (RAS) Library and the School of Oriental and African Studies (SOAS) Library. There ia also a collection of manuscripts kept in the British Library and several other libraries. Most of the manuscripts were brought to London by British officers who had worked in Malaya, in addition to some which went through the process of buying and selling, presented as gifts and so on.

\section{Royal Asiatic Society Library, London}

1. Undang-undang Raja Melaka (Farquhar 1) written by Yahya bin Abdul Wahid, a native of Malacca who lived in Kampung Melayu, Malacca, dated 1816. A manuscript written in Jawi script that is clear and easy to read, in black and red ink. The paper has the 1806 watermark. The manuscript measures $21.4 \mathrm{~cm} \times 17.6 \mathrm{~cm}$, complete with introduction and colophon. Its contents consist of the story of Sultan Iskandar Syah entering Malacca, embracing Islam and changing his name to Sultan Muhammad Syah. The contents also include 66 chapters of customs and traditions and laws practiced in Malacca. This manuscript is a different version from that of Undang-undang Melaka which was published by Liaw Yock Fang (1976). ${ }^{4}$ In the colophon section the name of the 
manuscript's owner is stated as Mejar Pakar which refers to William Farquhar, as in the transliteration below ${ }^{5}$ :

Tamat surat ini kepada dua belas haribulan Rabiul Akhir hari Sabtu jam pukul sembilan sanat 1232. Adapun yang menyuratnya kerani Yahya bin Abdul Wahid anak Melaka daerah Kampung Melayu, dan yang punya surat ini Tuan Raja Mejar Pakar yang memerintahkan kota Melaka adanya.

[This letter is completed on Saturday, twefth of Rabiul Akhir, at twelve o'clock 1232. Is is hereby stated that the copyist is Yahya bin Abdul Wahid, a native of Malacca of the district of Kampung Melayu, and the owner of this letter is Mejar Pakar who rules the city of Malacca.]

2. Hikayat Raja Iskandar Zulkarnain (Farquhar 2), another manuscript written by Yahya bin Abdul Wahid in Malacca, dated 1816. The manuscript consists of three volumes with hardcover, brown in colour. The manuscript is in good condition, neat and without any damage, The paper is yellowish in colour and measures $22.2 \mathrm{~cm} \mathrm{x} 18.2 \mathrm{~cm}$ and totals 202 pages. Written in Jawi script in black and red ink. The manuscript demonstrates the art of Jawi script writing and illustrations of colourful flowers. The contents of the manuscript is a different version from that of Hikayat Iskandar Zulkarnain which was published by Khalid M. Hussain (1986) (see Figure 1).

3. Sejarah Melayu (Farquhar 5) written by Yahya bin Abdul Wahid in Malacca in the year 1814. The manuscript is neatly bound, blue in color, still in good condition without any damage. The manuscript has 263 pages in Jawi script, complete with introduction and colophon. On the opening page is a note and signature by R.O. Winstedt dated 19 July 1950. Therefore, in this collection of manuscripts kept in the Royal Asiatic Society, London there are at least three manuscripts by Yahya bin Abdul Wahid. In the colophon section of Farquhar 1 manuscript is stated Yahya bin Abdul Wahid's occupation as a clerk, most probably a clerk working for William Farquhar in Malacca at that time. 
JELANI HARUN
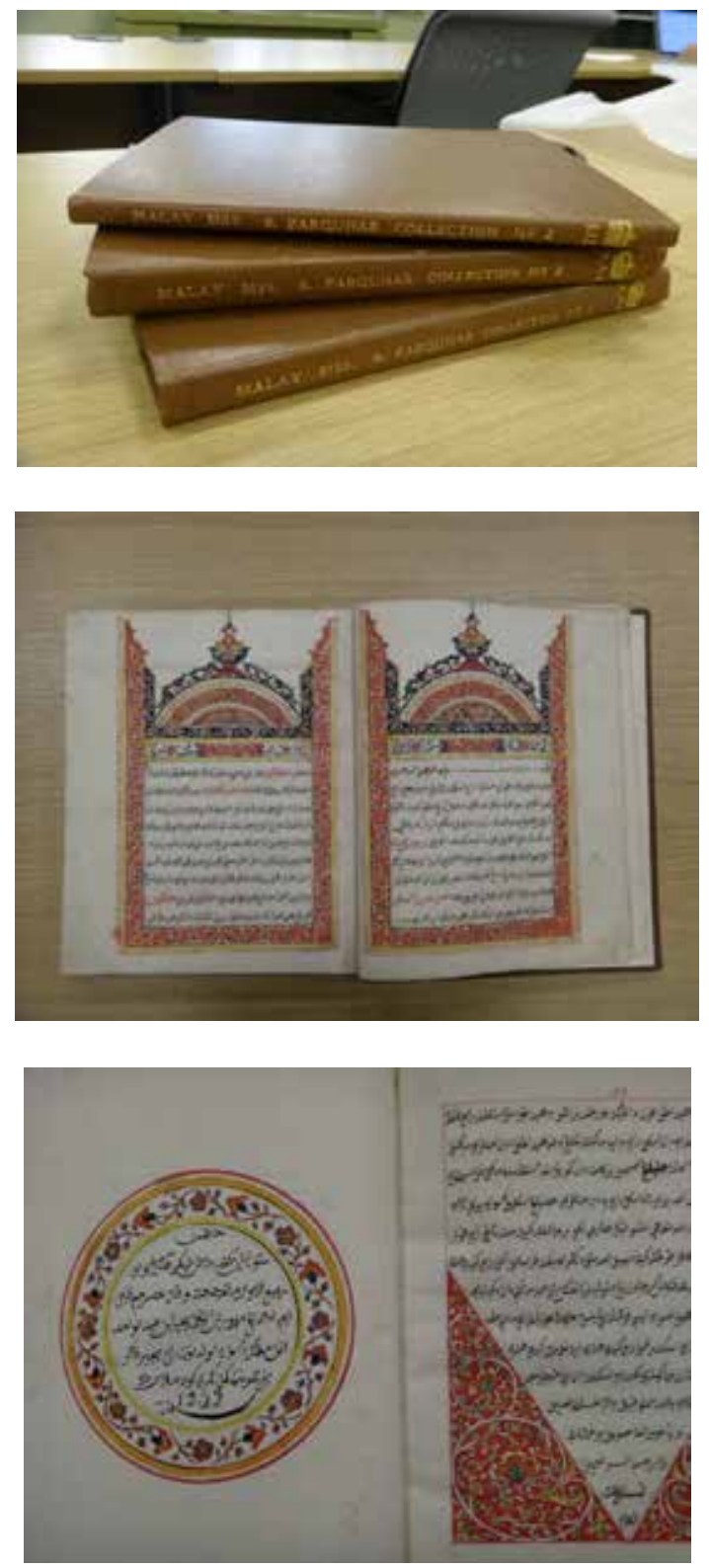

Figure 1 Hikayat Raja Iskandar Zulkarnain (RAS Farquhar 2). (Source: Writer's Collection) 
Among the manuscripts kept in the Royal Asiatic Society, there are several manuscripts that state the names of the owners such as Encik Muhammad bin Haji Abdul Fatah. One such manuscript is Sejarah Melayu (Maxwell 26) owned by Encik Muhammad bin Haji Abdul Fatah, dated 1898. He is also the owner of the manuscripts Hikayat Serangga Bayu (Maxwell 59), Adat Segala Raja-raja Melayu (Maxwell 60), Syair Makrifat (Maxwell 63), Hikayat Shahi Mardan (Maxwell 76), Hikayat Maharaja Ali (Maxwell 81), Syair Selindung Delima (Maxwell 82), and Hikayat Nabi Mikraj (Maxwell 97). In the future, further research should be made on the identity of Encik Muhammad bin Haji Abdul Fatah, especially in order to ascertain whether he was just the owner of the manuscripts or was he the writer or a copyist of Malay manuscripts. The following is the colophon for Hikayat Raja-raja Berputera (Maxwell 60) that states the name of the owner as Encik Muhammad bin Haji Abdul Fatah:

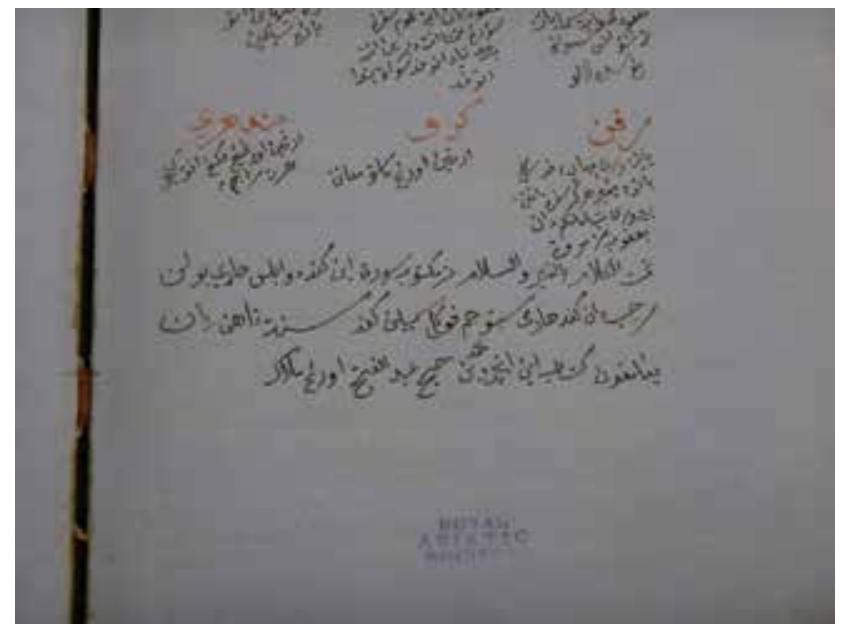

Figure 2 Hikayat Raja-raja Berputera (RAS Maxwell 60).

(Source: Writer's Collection)

\section{School of Oriental and African Studies Library, London}

1. Taj al-Salatin (MS 21039) is the copy made by Abdul Rahman bin Mustafa in Malacca, dated 1873. The manuscript is still in good condition and bound with yellow patterned paper. Written in Jawi script in black and red ink on blue paper measuring $25 \mathrm{~cm} \times 19.5 \mathrm{~cm}$. The writing is very neat without any mistakes and shows the meticulousness of a writer. 
The contents consist of 24 chapters of Taj al-Salatin covering 135 pages. The whole 24 chapters are similar to the contents of Taj al-Salatin that was published by Khalid M. Hussain (1992). On the colophon section is stated the following information, as in the transliteration below:

Disalin kitab ini di dalam Negeri Melaka. Tamatlah kepada empat belas haribulan Jamadil Awal kepada hari Arba' waktu Asar jam pukul empat petang sanat 1290 Hijrat al-nabuwwat. Wakatibuhu Abdul Rahman bin Mustafa.

[This book is copied in the state of Malacca. It is completed on the afternoon of fourteenth of Jamadil Awal, on Wednesday at 4 o'clock 1290 Hijrah. Writer Abdul Rahman bin Mustafa.]

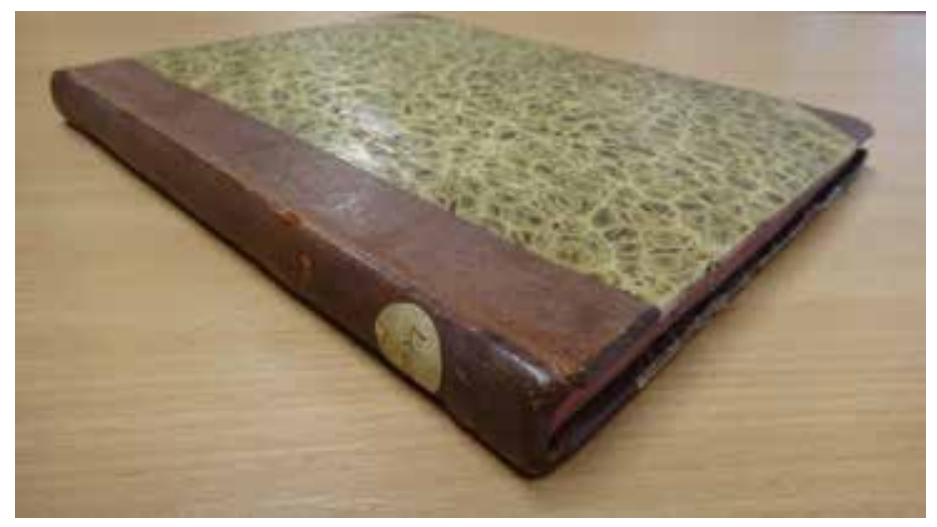

Figure 3 Taj al-Salatin (SOAS MS 21039).

(Source: Writer's Collection)

2. Hikayat Raja-raja Kahwin (MS 36497 ). The manuscript was written in Malacca in 1886 by Muhammad Saidi bin Maidin. The manuscript measures $22 \mathrm{~cm} \times 16 \mathrm{~cm}$, contains 15 lines in a page and consists of 122 pages. The paper used for the manuscript is white in colour and rather thin and bound with whitish patterned paper. The contents describe the procedures during the wedding ceremony of the rulers that show a lot of similarity with the wedding customs of Malay rulers as described in Adat Raja-raja Melayu. The name of the writer is stated on the colophon as in the transliteration below: 
Telah khatamlah kita suratkan akan segala hal yang ada di dalam naskhah ini apa yang ada tersurat itulah kita suratkan adanya. Alfaqir al-haqir Muhammad Saidi bin Maidin, Melaka, tersurat kepada 30 Rabiul Awal 1303, Melayu.

[We have completed writing what we set out to write in this text. Alfaqir al-haqir Muhammad Saidi bin Maidin, Melaka, written on 30 Rabiul Awal 1303, Malay.]

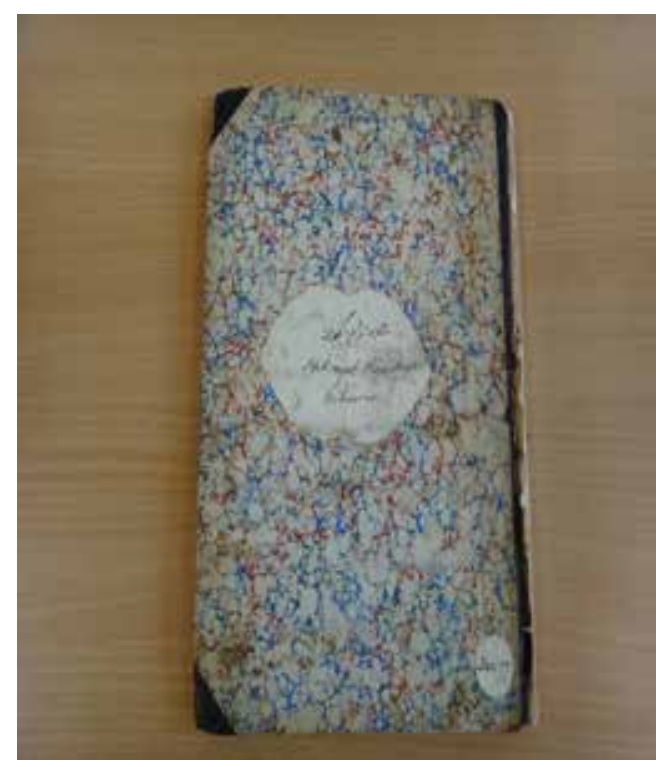

Figure 4 Hikayat Raja-raja Kahwin (SOAS MS 36497).

(Source: Writer's Collection)

3. Hikayat Hang Tuah (MS 37075) was copied in Malacca in 1882 by Muhammad Thahir bin Abdul Samad. Consists of two volumes totalling 778 pages. The manuscript is leather bound and was once the property of D.F.A Hervey. ${ }^{6}$ The manuscript is written in Jawi in black and red ink, and measures $32.5 \mathrm{~cm} \times 20 \mathrm{~cm}$. Several opening pages are decorated with colourful frames. The manuscript looks luxurious and has been carefully refurbished by SOAS Library. The colophon is stated at the end of the second volume as in the transliteration follow: 
Tamatlah surat Hikayat Hang Tuah ini di dalam Negeri Melaka di dalam Kampung Lambungan. Bermula yang empunya hikayat ini iaitu Tuan Harvey adanya. Telah selesai menyurat hikayat ini kepada tiga haribulan tahun 1882. Alhaqir Muhammad Thahir bin Abdul Samad wassalam.

[The text of Hikayat Hang Tuah is completed in Malacca in Kampung Lambungan. It was originally owned by Tuan Harvey. It is completed on the 3rd in 1882. Alhaqir Muhammad Thahir bin Abdul Samad. Wassalam.]
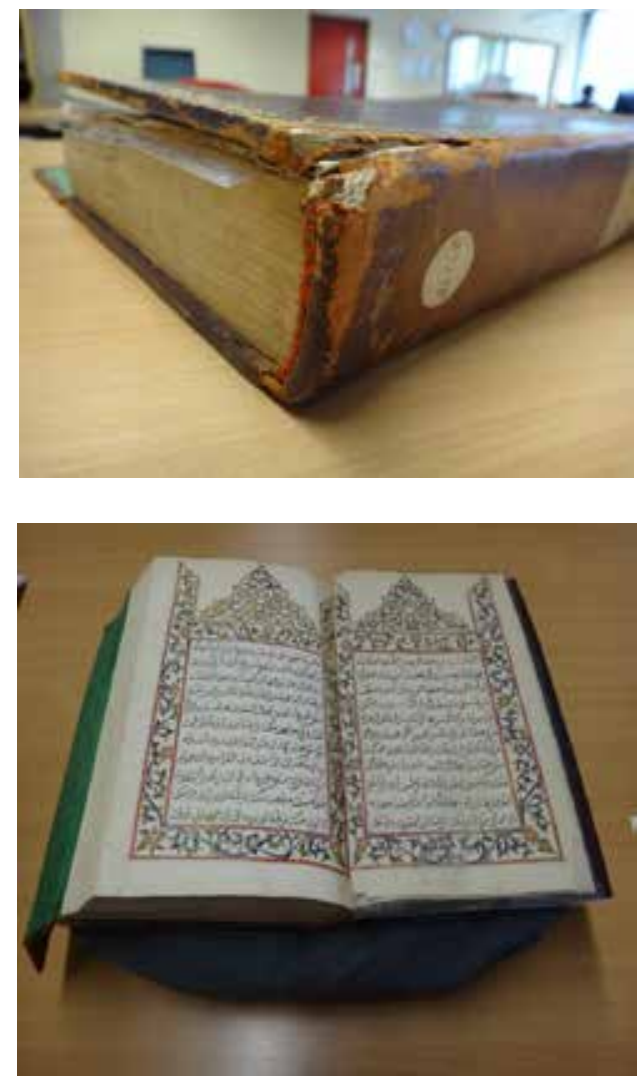

Figure 5 Hikayat Hang Tuah (SOAS MS 37075).

(Source: Writer's Collection) 


\section{Adat Raja-raja Melayu}

Initial academic study on the manuscript Adat Raja-raja Melayu was conducted by Panuti H.M. Sudjiman as his research material for his doctoral degree at Australian National University in 1979. This doctoral thesis was then published by Universitas Indonesia, Jakarta in 1996. This publication played a big role in giving prominence to Adat Raja-raja Melayu in the public domain. However, Panuti in publishing Adat Raja-raja Melayu based it on the main manuscripts kept in Leiden without explaining clearly where the manuscripts were written.

The history of the writing of Adat Raja-raja Melayu started with a request by the Dutch Governor of Malacca by the name of De Bruyn (17771785) that a manuscript be written to describe the customs of Malay rulers. The request was finally fulfilled by a copyist living in Tengkera, Malacca by the name Abdulmuhit in 1779. As a result, Adat Raja-raja Melayu is a work that originated in Malacca in 1779 and became one of the great and importants works in the literature of Malacca. According to Panuti (1996, p. 12), early research was done on Adat Raja-raja Melayu by G.K (1892) and Van Ronkel (1929). All the the romanised transliteration for the text was then done by Tarjan Hadidjaja and published by Pustaka Antara, Kuala Lumpur in 1964.

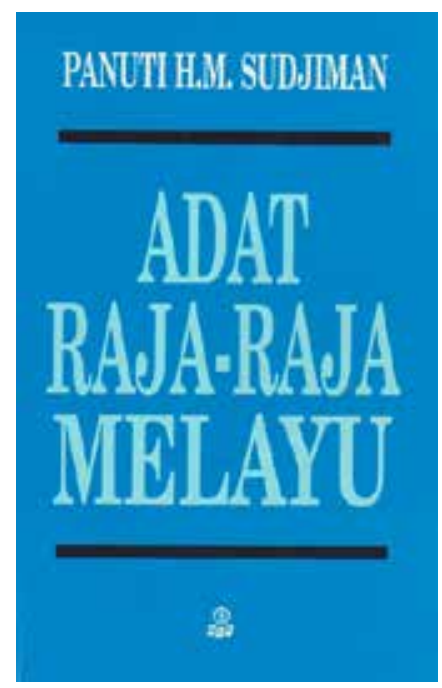

Figure 6 Adat Raja-raja Melayu by Panuti.

(Source: Writer's Collection) 
The contents of Adat Raja-raja Melayu do not cover the customs and traditions of Malay rulers as a whole, but focuses on the customary practices of the rulers during coronation, weddings, celebration of birth and death. However, each description of the customs is recorded in detail and contains a lot of important information about the customs and traditions of Malay sultans in the past. Some of these customs are still being practised at the courts of Malay rulers to this day, in addition to newer customs. This makes the manuscript Adat Raja-raja Melayu a valuable piece of literature that records the variety of customary practices of Malay courts to this day.

The early publication of Adat Raja-raja Melayu by Tardjan dan Panuti does not mean that the manuscript should not be republished. Both of these early publications are based on important manuscripts kept in Leiden. Since Adat Raja-raja Melayu is a manuscript that originates from Malacca, it is only right that the manuscript is republished based on the manuscript that was written in Malacca, and it would be best written by a writer from Malacca itself. At least two manuscripts are available which can be considered for a new publication of Adat Raja-raja Melayu

1. Adat Segala Raja-raja Melayu (SOAS MS 21042) by Abdul Rahman bin Mustafa in Malacca, dated 1779. The manuscript consists of 80 pages, blue in colour and written in black and red ink, bound by greenish patterned paper. The Jawi script is easily read and written in black and red ink. The manuscript measures $24.5 \mathrm{~cm} \mathrm{x} 18.5 \mathrm{~cm}$ is complete with an introduction and colophon. On the colophon page is the following which is transliterated as:

Tamat al-kalam bil khair wassalam. Termaktub hikayat ini sehari bulan Rabiul Akhir hari yaum al-khamis. Wa katibuhu Abdul Rahman bin almarhum ayahanda Mustafa di dalam Negeri Melaka, Kampung Telengkera adanya.

[The writing is completed, wassalam. It is completed in Rabiul Akhir on a Thursday. The writer is Abdul Rahman bin Almarhum ayahanda Mustafa in the State of Malacca, Kampung Telengkera.] 

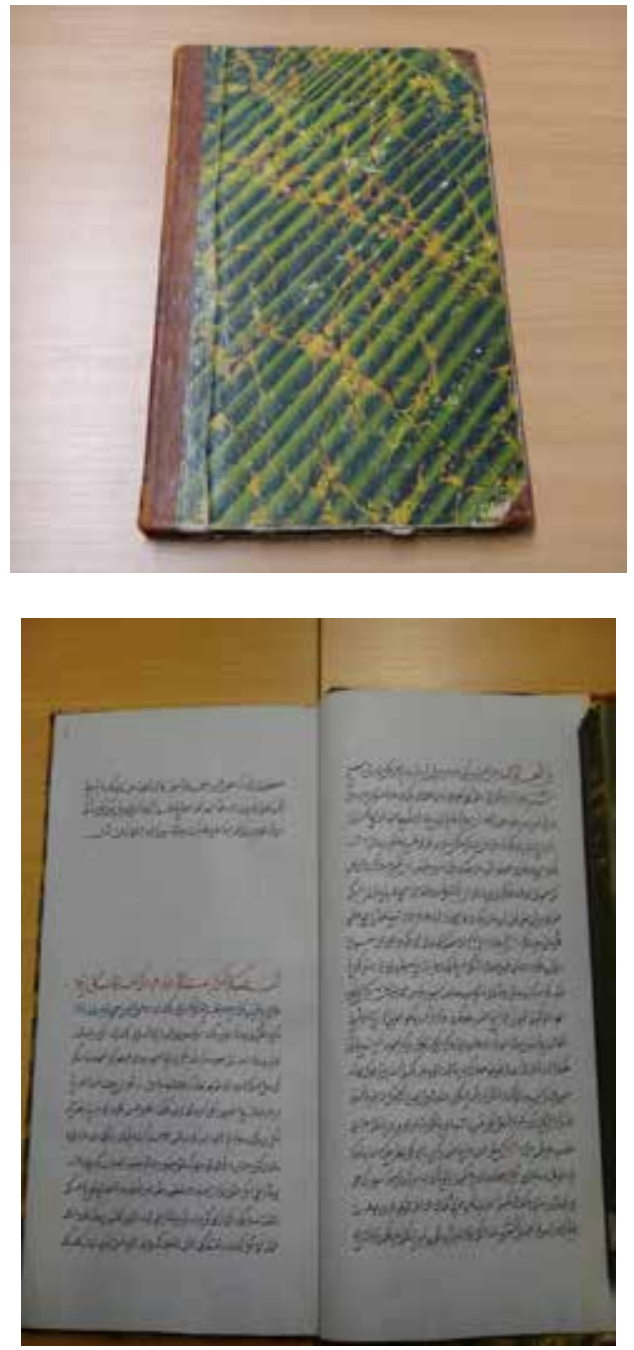

Figure 7 Adat Segala Raja-raja Melayu (SOAS MS 21042). (Source: Writer's Collection)

\section{Adat Segala Raja-raja Melayu (RAS Maxwell 60)} The Royal Asiatic Society Library also owns a manuscript Adat Segala Raja-raja Melayu (RAS Maxwell 60) which is no less important. The manuscript is still in good condition, bound with patterned hard paper 
that is black and yellowish in colour, and consists of 119 pages. On the external cover is written the title of the manuscript: "Ini hikayat raja-raja berputera" ["This is the story of Sultans and their Descendants"]. The manuscript measures $20.2 \mathrm{~cm}$ x $16.2 \mathrm{~cm}$ in black and red ink. The paper is blue in colour, unlined and similar to the paper used in MS 21042 which is kept in SOAS. However, the Maxwell 60 manuscript does not state clearly where the manuscript was copied and who the copyist was. Hence the MS $21042 \mathrm{kept}$ in SOAS is still the best manuscript that can be used as the basis for publication of a new version of Adat-adat Raja-raja Melayu. Other manuscripts can be used as comparison in order to produce an edited version that is more critical and academic.
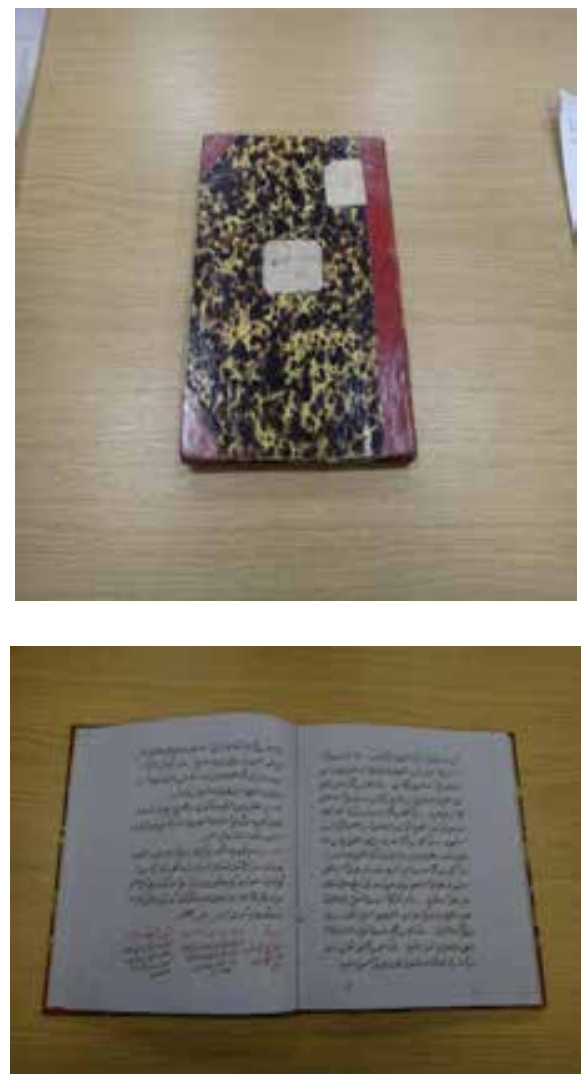

Figure 8 Adat Segala Raja-raja Melayu (RAS Maxwell 60). (Source: Writer's Collection) 


\section{CONCLUSION}

The existence of manuscripts from Malacca in London provides clear proof of the history of literature in Malacca which continued to flourish in the 18th and 19th centuries. Until now, there has not been many detailed research on these manuscripts conducted by scholars, including in the studies which are related to sociocultural issues of the Malaccan society in the past. The names of the manuscript writers from Malacca such as Yahya bin Abdul Wahid, Muhammad bin Tuan Haji Abdul Fatah, Abdul Rahman bin Mustafa, Muhammad Saidi bin Maidin and Muhammad Thahir bin Abdul Samad may just disappear from public awareness if no effort is made to highlight their contribution in the history of Malay literature and culture in Malacca.

Further studies and more in-depth ones are needed from scholars and philologists in order to highlight manuscripts from Malacca to the public, especially those from natives of Malacca state or by institutions which are responsible for the preservation of Malacca's history and culture. More importantly, it is time for these major or great works related to the history of the Malacca Sultanate such as the descriptions found in Sulalatus Salatin, Hikayat Hang Tuah, Undang-undang Melaka and Undang-undang Laut Melaka be republished based on manuscripts written by natives of Malacca so that the identity and preservation of Malacca's literary history continues through the ages. This article is also emphasizing that Adat Raja-raja Melayu be republished in a new form, particularly in using the manuscripts kept in London as these manuscripts are the product of Malaccan writers.

\section{NOTES}

1 See further discussion in Muhammad Yusoff Hashim (1992), Kratz (2004) and Braginsky (2011).

2 Until today, scholars are not in agreement about when Hikayat Hang Tuah was written, but there is a high possibility it was written in Johore in the middle of the 18th century. The name of the writer has still not been determined with certainty.

3 Research into the manuscripts in London was done in June 2016 and covers manuscripts kept in the School of Oriental and African Studies library, the Royal Asiatic Society and the British Library. Brief descriptions of the manuscripts and several examples of transliteration of the manuscripts given in this article are based on the writer's own research in London. Further explanation of the method of Malay manuscript description can be referred to in Jelani Harun (2009).

4 See brief explanation in Liaw Yock Fang (1976, p. 22). 
5 William Farquhar (1774-1839) was the British Resident in Malacca in the period 1808-1818 prior to becoming the British Resident in Singapore from 1819-1823.

6 D.F.A. Hervey was a British officer who once served in Malacca (Ricklefs and Voorhoeve, 1977, p. 162).

\section{RUJUKAN}

Abu Hassan Sham, 1995. Hukum Kanun Melaka. Melaka: Perbadanan Muzium Melaka.

A. Samad Ahmad, 1996. Sulalatus Salatin (Sejarah Melayu). Kuala Lumpur: Dewan Bahasa dan Pustaka.

Braginsky, V.I. 2004. A Heritage of traditional Malay Literature. Leiden: KITLV Press.

Cheah Boon Kheng, 1998. Sejarah Melayu The Malay Annals. MBRAS Reprint No. 17.

Hikayat Hang Tuah dikaji dan diperkenalkan oleh Kassim Ahmad, 1997. Kuala

Lumpur: Yayasan Karyawan.

Jelani Harun, 2009. Bustan al-Salatin: A Malay mirror for rulers. Penang: USM Press.

Kassim Ahmad, 1997. Hikayat Hang Tuah. Kuala Lumpur: Dewan Bahasa dan Pustaka.

Khalid M. Hussain, 1986. Hikayat Iskandar Zulkarnain. Kuala Lumpur: Yayasan Karyawan.

Khalid M. Hussain, 1992. Taj al-Salatin. Kuala Lumpur: Dewan Bahasa dan Pustaka. Kratz, E.U., 2011. "Sulalat al-Salatin dan Hikayat Hang Tuah: Sumbangan dan Pandangan Kesarjanaan Barat terhadap Dua Karya Agung Melayu” Kertas Kerja Persidangan Antarabangsa Karya Agung Melayu, 1-2 November 2011, Seri Negeri, Air Keroh, Melaka, anjuran Yayasan Karyawan dan kerajaan negeri Melaka.

Liaw Yock Fang, 1976. Undang-Undang Melaka. The Hague: Martinus Nijhoff. Mariyam Salim, 2005. Undang-Undang laut. Kuala Lumpur: Dewan Bahasa dan Pustaka.

Muhammad Haji Salleh. (1997) Sulalatus al-Salatin. Kuala Lumpur: Yayasan Karyawan.

Muhammad Yusoff Hashim, 1992. The Malay Sultanate of Malacca. Kuala Lumpur: Dewan Bahasa dan Pustaka.

Panuti H.M. Sudjiman, 1996. Adat Raja-Raja Melayu. Jakarta: Penerbit Universitas Indonesia.

Ricklefs, M.C. \& Voorhoeve, P., 1977. Indonesian manuscripts in Great Britain. Oxford: Oxford University Press.

Robson, S., 1988. Principles of Indonesian philology. Dordrecht-Holland: Foris Publications. 
MALAY LITERATURE VOLUME 31 NUMBER 1 JUNE 2018

Shellabear, W.G., 1996. Sejarah Melayu. Shah Alam: Penerbit Fajar Bakti.

Ahmat Adam. (2016). Sulalat u's-Salatin. Kuala Lumpur: Yayasan Karyawan.

Tardjan Hadidjaja. (1964). Adat Raja-Raja Melayu. Kuala Lumpur: Pustaka Antara.

Liaw Yock Fang. (2003). Undang-Undang Melaka dan Undang-Undang Laut.

Kuala Lumpur: Yayasan Karyawan.

Received: 24 January 2018

Accepted: 22 Mei 2018 